\title{
POLITIK HUKUM PERTANAHAN DALAM RANGKA PERCEPATAN PENDAFTARAN TANAH DI INDONESIA
}

\author{
Satriyo Ardi Kartono \\ Magister Hukum Fakultas Hukum Universitas Pembangunan Nasional Veteran Jakarta \\ Email : ardi.satriyo@yahoo.co.id
}

\begin{abstract}
Land registration is a government project to guarantee legal certainty and protection of land ownership throughout the territory of the Republic of Indonesia. Land registration is an important thing, apart from being a form of legal certainty and protection from the government, it also aims to create an orderly administration, prevent land conflicts and land disputes, and improve people's lives. Government policies regarding land registration have existed since Indonesia's independence, the old order, the new order until the current reformation order. However, in its journey land registration in Indonesia has not been maximized. The number of registered land plots is only \pm 58 million of the total \pm 126 million land plots, so that there are \pm 68 million land plots that have not been registered. Therefore, to accelerate land registration progress, the Government makes a National Strategic Project policy namely Complete Systematic Land Registration. This type of research is a normative juridical with a statutory approach and analysis approach. This study aims to determine and analyze national land policies in the context of accelerating land registration in Indonesia from the Old Order to the current Reformation Order.
\end{abstract}

Keywords : Politics of Land Law, Land Registration, Complete Systematic Land Registration.

\begin{abstract}
Abstrak
Pendaftaran tanah merupakan kegiatan dari pemerintah untuk menjamin kepastian dan perlindungan hukum atas kepemilikan tanah di seluruh wilayah Republik Indonesia. Pendaftaran tanah merupakan hal yang penting, selain karena sebagai bentuk kepastian dan perlindungan hukum dari pemerintah, juga bertujuan untuk mewujudkan tertib administrasi, mencegah terjadinya konflik dan sengketa pertanahan, dan meningkatkan taraf hidup masyarakat. Kebijakan pemerintah mengenai pendaftaran tanah sudah ada sejak Indonesia merdeka, masa orde lama, orde baru hingga orde reformasi sekarang ini. Namun, dalam perjalanannya pendaftaran tanah di Indonesia belum maksimal. Jumlah bidang tanah yang sudah terdaftar baru \pm 58 juta dari total \pm 126 juta bidang tanah, sehingga terdapat \pm 68 juta bidang tanah yang belum terdaftar. Oleh karena itu, untuk mempercepat pendaftaran tanah, Pemerintah membuat kebijakan Proyek Strategis Nasional yaitu Pendaftaran Tanah Sistematis Lengkap. Tipe penelitian ini adalah yuridis normatif dengan pendekatan perundangundangan dan pendekatan analisis. Penelitian ini bertujuan untuk mengetahui dan menganalisis kebijakan pertanahan nasional dalam rangka percepatan pendaftaran tanah di Indonesia sejak Orde Lama hingga Orde Reformasi sekarang ini.
\end{abstract}

Kata kunci : Politik Hukum Pertanahan, Pendaftaran Tanah, Pendaftaran Tanah Sistematis Lengkap. 


\section{Pendahuluan}

Tanah merupakan kebutuhan dasar manusia yang sangat fundamental dalam kehidupan suatu masyarakat, khususnya bagi masyarakat Indonesia yang merupakan masyarakat agraris yang sangat erat kaitannya dengan tanah dalam memenuhi kebutuhan hidup. Sejak lahir sampai meninggal manusia membutuhkan tanah yang digunakan untuk berbagai kebutuhan, antara lain untuk mendirikan tempat untuk berlindung dari panas dan hujan, juga digunakan untuk bercocok tanam dan investasi. Keniscayaan dan Kebutuhan memiliki tanah sudah tertanam sedemikian mendalam dalam lintasan sejarah kehidupan manusia, dari tanah mengalir semangat harga diri, kemakmuran, kekuasaan, dan kesakralan. ${ }^{1}$

Dalam penggunaan dan pengusahaan tanah bagi kehidupan manusia, tanah memberikan berbagai nilai bagi manusia (multiple value), yaitu sedikitnya 4 (empat) nilai, yang meliputi nilai sosial, ekonomi, budaya, dan religius. ${ }^{2}$ Tanah memiliki nilai sosial karena tanah dapat melambangkan seseorang nilai kehormatan dan kebanggaan dalam kehidupan bermasyarakat. Nilai ekonomi dari tanah terletak pada penggunaan dan pemanfaatan tanah yang digunakan untuk pertanian, terlebih pada masa ini nilai tanah semakin lama menjadi semakin tinggi sehingga banyak dimanfaatkan untuk investasi jangka panjang maupun jangka pendek.

Tidak dapat dipungkiri hubungan manusia dengan tanah sangatlah dekat, manusia tanpa adanya tanah tidak mungkin dapat melangsungkan kehidupan bermasyarakat. Dengan demikian, apabila hak-hak penguasaan atas tanah beralih kepada pihak lain, bukan saja akan menyebabkan kehilangan sumber kehidupan, melainkan pula akan mempunyai dampak terhadap nilai-nilai sosial maupun identitas budaya masyarakat yang bersangkutan. ${ }^{3}$ Dengan begitu berharganya tanah bagi kehidupan seseorang, maka tidak sedikit orang yang rela mengorbankan nyawa untuk berjuang mempertahankan tanahnya dan tidak sedikit pula terjadi pertumpahan darah karena perselisihan tanah.

Sumber daya alam Indonesia yang melimpah menjadikan banyak orang ingin memiliki dan menguasainya, jika tidak ada hukum yang mengatur maka akan menimbulkan konflik dan sengketa bagi masyarakat. Oleh karena itu, para Pendiri Negara ini menitipkan satu amanah melalui Pasal 33 ayat (3) Undang-Undang Dasar RI 1945 agar mengatur penggunaan sumber daya alam termasuk tanah untuk meningkatkan kemakmuran seluruh rakyat Indonesia. ${ }^{4}$ Amanah tersebut selanjutnya dikonkretkan dalam Undang-Undang Nomor 5 tahun 1960 tentang Peraturan Dasar Pokok-Pokok Agraria (UUPA), yang memuat pokok-pokok dari Hukum Tanah Nasional Indonesia. Namun, sebagai ketentuan yang bersifat pokok, masih diperlukan pengaturan yang bersifat lebih rinci sebagai pelaksanaan dari UUPA.

Pasal 19 ayat (1) UUPA mengamanatkan adanya pendaftaran tanah di seluruh

${ }^{1}$ Nurhasan Ismail, Hukum Agraria Dalam Tantangan Perubahan, Malang, Setara Press, 2018, Hlm. 2.

${ }^{2}$ Nia Kurniati, Hukum Agraria Sengketa Pertanahan Penyelesaiannya Melalui Arbitrase Dalam Teori dan Praktik, Bandung, PT Refika Aditama, 2016, Hlm. 2.

${ }^{3}$ Ibid., Hlm. 3.

${ }^{4}$ Nurhasan Ismail, Op. Cit. Hlm. 3. 
Wilayah Republik Indonesia untuk menjamin kepastian hukum yang diatur dengan peraturan pemerintah. Sebagai tindak lanjut dari Pasal 19 ayat (1) UUPA tersebut, maka Pemerintah membuat Peraturan Pemerintah Nomor 10 Tahun 1961 tentang Pendaftaran Tanah. Dalam kenyataannya pendaftaran tanah yang diselenggarakan berdasarkan Peraturan Pemerintah Nomor 10 Tahun 1961 tersebut selama lebih dari 35 tahun belum cukup memberikan hasil yang memuaskan. Dari sekitar 55 juta bidang tanah hak yang memenuhi syarat untuk didaftar, baru lebih kurang 16,3 juta bidang yang sudah didaftar. ${ }^{5}$ Peraturan Pemerintah Nomor 10 Tahun 1961 tentang Pendaftaran Tanah dipandang tidak dapat lagi sepenuhnya mendukung tercapainya hasil yang lebih nyata pada pembangunan nasional, sehingga perlu dilakukan penyempurnaan dengan Peraturan Pemerintah Nomor 24 Tahun 1997 tentang Pendaftaran Tanah.

Pendaftaran tanah bertujuan untuk memberikan kepastian hukum dan perlindungan hukum kepada pemegang hak atas suatu bidang tanah. Pendaftaran tanah juga bertujuan untuk mewujudkan tertib administrasi, mencegah terjadinya konflik dan sengketa pertanahan, dan meningkatkan taraf hidup masyarakat. Dengan terselenggaranya pendaftaran tanah, maka pemegang hak atas tanah memiliki kepastian dan dilindungi secara hukum karena sertipikat hak atas tanah memiliki kekuatan pembuktian yang sempurna, selama belum dibuktikan sebaliknya, data fisik dan data yuridis yang dicantumkan dalam sertipikat harus diterima sebagai data yang benar.

Pemerintah telah membuat kebijakan-kebijakan percepatan pendaftaran tanah, yaitu Proyek Operasi Nasional Agraria (PRONA). Sebenarnya kebijakan PRONA sudah ada pada saat berlakunya Peraturan Pemerintah Nomor 10 Tahun 1961 tentang Pendaftaran Tanah. Pada saat berlaku Peraturan Pemerintah Nomor 24 Tahun 1997 tentang Pendaftaran Tanah, Pemerintah melanjutkan kebijakan PRONA tersebut demi percepatan pendaftaran tanah. Namun, pendaftaran tanah di Indonesia selama ini belum maksimal, jumlah bidang tanah yang sudah terdaftar baru sekitar \pm 58 juta dari total \pm 126 juta bidang tanah Indonesia, artinya terdapat \pm 68 juta bidang tanah yang belum terdaftar. Dengan masih rendahnya pendaftaran tanah tersebut, sudah tentu akan menimbulkan berbagai permasalahan pertanahan. Permasalahan pertanahan yang seringkali terjadi di masyarakat antara lain, yaitu tidak adanya pemerataan dalam pemilikan dan atau penguasaan tanah; adanya penguasaan tanah tanpa izin yang berhak atau kuasanya; dan banyaknya sengketa batas. ${ }^{6}$

Pendaftaran tanah di Indonesia yang masih rendah selama ini membuat Pemerintah Indonesia membentuk regulasi percepatan pendaftaran tanah, yaitu melalui kebijakan Pendaftaran Tanah Sistematis Lengkap (PTSL). Dalam rangka percepatan pendaftaran tanah telah diterbitkan Peraturan Menteri Agraria dan Tata Ruang/Kepala BPN No. 35 Tahun 2016 tentang Percepatan Pelaksanaan Pendaftaran Tanah Sistematis Lengkap sebagaimana telah diubah dengan Peraturan Menteri Agraria dan Tata Ruang/ Kepala BPN No. 01 Tahun 2017 tentang Perubahan Atas Peraturan Menteri Agraria dan

5 Penjelasan Atas Peraturan Pemerintah Nomor 24 Tahun 1997 Tentang Pendaftaran Tanah.

${ }^{6}$ Sri Hajati, dkk. Buku Ajar Politik Hukum Pertanahan, Surabaya, Airlangga University Press, 2018. 
Tata Ruang/Kepala BPN No. 35 Tahun 2016 tentang Percepatan Pelaksanaan Pendaftaran Tanah Sistematis Lengkap, selanjutnya diamandemen kembali menjadi Peraturan Menteri Agraria dan Tata Ruang/Kepala BPN No. 12 Tahun 2017 tentang Percepatan Pendaftaran Tanah Sistematis Lengkap dan terakhir diubah kembali menjadi Peraturan Menteri Agraria dan Tata Ruang/Kepala BPN No. 6 Tahun 2018 tentang Pendaftaran Tanah Sistematis Lengkap.

Kebijakan PTSL memiliki perbedaan yang mendasar dibandingkan dengan PRONA, karena jumlah bidang tanah dalam pendaftaran tanah pertama kali melalui PRONA bersifat terbatas, sedangkan pada pendaftaran tanah melalui PTSL tidak dibatasi jumlahnya. Hal tersebut sebagaimana yang diatur dalam Pasal 1 Angka 2 Peraturan Menteri Agraria dan Tata Ruang/Kepala BPN No. 6 Tahun 2018 tentang Pendaftaran Tanah Sistematis Lengkap bahwa "PTSL merupakan kegiatan pendaftaran tanah untuk pertama kali yang dilakukan secara serentak bagi semua objek pendaftaran tanah di seluruh wilayah Republik Indonesia dalam satu wilayah desa/kelurahan atau nama lainnya yang setingkat dengan itu, yang meliputi pengumpulan data fisik dan data yuridis mengenai satu atau beberapa objek pendaftaran tanah untuk keperluan pendaftarannya".

PTSL tidak dapat dilaksanakan oleh Kementerian Agraria dan Tata Ruang/Badan Pertanahan Nasional sendiri, namun memerlukan sinergi dari berbagai instansi yang terkait. Oleh karena itu, untuk menyukseskan kebijakan PTSL, Presiden mengeluarkan Instruksi Presiden Nomor 2 Tahun 2018 Tentang Percepatan Pendaftaran Tanah Sistematis Lengkap Di Seluruh Wilayah Republik Indonesia. Dalam Inpres tersebut, Presiden menginstruksikan kepada para Menteri terkait, Kepala Kepolisian, Jaksa Agung, Kepala Lembaga dan para Kepala Daerah untuk mengambil langkahlangkah yang diperlukan sesuai dengan tugas, fungsi, dan kewenangan masing-masing dalam rangka pelaksanaan percepatan Pendaftaran Tanah secara Sistematis Lengkap di seluruh wilayah Indonesia sebagai gerakan nasional dengan tujuan utama agar terwujudnya pendaftaran tanah secara lengkap di seluruh wilayah Indonesia dalam rangka mendukung Proyek Strategis Nasional. Berdasarkan uraian latar belakang di atas, yang menjadi rumusan masalah adalah bagaimana politik hukum pertanahan dalam rangka percepatan pendaftaran tanah di Indonesia.

\section{Metode Penelitian}

Metode yang digunakan dalam penelitian ini adalah Yuridis Normatif (legal research) yaitu penelitian yang difokuskan untuk menguji penerapan kaidah atau normanorma dalam hukum positif yang berlaku.

\section{Pembahasan}

\subsection{Politik Hukum Pertanahan Dalam Rangka Percepatan Pendaftaran Tanah Di Indonesia}

Menurut Kamus Besar Indonesia (KBBI), politik/po ti tik/ n 1 (pengetahuan) mengenai ketatanegaraan atau kenegaraan (seperti tentang sistem pemerintahan, dasar pemerintahan); 2 segala urusan dan tindakan (kebijakan, siasat, dan sebagainya) mengenai pemerintahan negara atau terhadap negara lain; 3 cara bertindak (dalam menghadapi atau menangani suatu masalah); kebijaksanaan. David Easton 
menjelaskan bahwa politik adalah satu bentuk tertentu dari tindakan sosial, yakni bentuk tindakan yang menjamin pengambilan dan pelaksanaan keputusan-keputusan, serta definisi atas bidang penerapannya. ${ }^{7}$

Menurut Satjipto Raharjo, politik hukum adalah aktivitas yang menentukan pilihan mengenai tujuan dan cara-cara yang hendak dipakai untuk mencapai tujuan hukum dalam masyarakat. ${ }^{8}$ Politik hukum pertanahan adalah kebijakan pemerintah di bidang pertanahan yang ditujukan untuk peruntukan dan penggunaan penguasa atau pemilik tanah, peruntukan penggunaan tanah untuk menjamin perlindungan hukum dan meningkatkan kesejahteraan serta mendorong kegiatan ekonomi melalui pemberlakuan Undang-Undang Pertanahan dan Peraturan Pelaksanaannya. ${ }^{9}$

Politik hukum pertanahan di Indonesia sebagai bagian politik hukum ditujukan untuk menyesuaikan hukum agraria yang berlaku dengan etik (norma kebaikan) hukum yang umum, etik hukum agraria yang khusus bagi Indonesia dan keadaan kepentingan dan kebutuhan di dalam masyarakat, sehingga mempunyai corak pedagogis juga, ialah memberi petunjuk merupakan pedoman bagi perkembangan agraria untuk memperoleh pembangunan dalam lapangan agraria yang diperlukan. ${ }^{10}$ Prinsip yang dijadikan dasar bertindak dalam bidang agraria bukanlah berdasarkan prinsip dagang, tetapi suatu prinsip yang lebih tinggi, suatu pandangan hidup yang luhur, yang terdiri dari lima sila sebagai satu kesatuan bulat yang dinamakan Pancasila. ${ }^{11}$

Undang-Undang Dasar RI 1945 merupakan dasar hukum utama yang formal bagi pembentukan hukum pertanahan nasional yang selanjutnya Undang-Undang Nomor 5 Tahun 1960 tentang Peraturan Dasar Pokok-Pokok Agraria (UUPA) menjadi dasar hukum utama bagi pembentukan peraturan perundang-undangan yang mengatur persoalan bumi, air, ruang angkasa, dan kekayaan alam yang terkandung di dalamnya. ${ }^{12}$ Tujuan politik hukum pertanahan nasional sejalan dengan tujuan dari UUD 1945 yaitu untuk melindungi segenap bangsa Indonesia, memajukan kesejahteraan umum, mencerdaskan kehidupan bangsa, dan ikut melaksanakan ketertiban dunia yang berdasarkan kemerdekaan, perdamaian abadi dan keadilan sosial. Arah politik hokum pertanahan nasional adalah untuk mewujudkan kemakmuran bagi seluruh rakyat Indonesia.

Tujuan UUPA sebagai alat politik hukum yang dimaksudkan untuk mewujudkan kemakmuran bagi seluruh rakyat Indonesia dapat dilihat dalam penjelasan umum I UUPA :

1. Meletakan dasar-dasar bagi penyusunan Hukum Agraria Nasional, yang akan merupakan alat untuk membawakan kemakmuran,

\footnotetext{
${ }^{7}$ Sri Hajati, dkk. Op Cit. Hlm. 4.

${ }^{8}$ Ibid., Hlm. 5.

${ }^{9}$ Ibid., Hlm. 7.

${ }^{10}$ Notonagoro, Politik Hukum dan Pembangunan Agraria Di Indonesia, Jakarta, Bina Aksara, 1984, Hlm. 1.

${ }^{11}$ Iman Soetiknjo, Politik Agraria Nasional, Yogyakarta, Gadjah Mada University Press, 1985.

12 Arba, Hukum Agraria Indonesia, Jakarta, Sinar Grafika, 2015.
} 
kebahagiaan, dan keadilan bagi negara dan rakyat, terutama rakyat tani dalam rangka masyarakat yang adil dan makmur.

2. Meletakkan dasar-dasar unutuk mengadakan kesatuan dan kesederhanaan dalam hukum pertanahan.

3. Meletakkan dasar-dasar untuk memberikan kepastian hukum mengenai hak-hak atas tanah bagi rakyat seluruhnya.

UUPA memang belum sempurna mengakomodasi pengaturan substansi norma dari semua unsur sumber daya agraria, namun dalam ketidaksempurnaannya tersebut, UUPA telah mampu meletakkan ketentuan-ketentuan pokok atau asas-asas hukum yang dapat dijadikan landasan bagi pembentukan undang-undang di bidang kehutanan, di bidang pertambangan, dan bidang sumber daya air beserta kekayaan alam lainnya, serta pengembangan peraturan pelaksanaan di bidang pertanahan. Ketentuan-ketentuan pokok atau asas-asas hukum yang tertuang dalam Pasal 1 sampai Pasal 15 UUPA sudah sesuai dengan kelima sila Pancasila. ${ }^{13}$

Hukum tanah nasional sebagaimana yang tertuang dalam UUPA memiliki sifat yang lebih unggul dibandingkan dengan ketentuan hukum agraria dalam zaman kolonial. UUPA menentang strategi Kapitalisme karena melahirkan kolonialisme, yang menyebabkan "penghisapan manusia atas manusia", UUPA juga menentang sosialisme yang "meniadakan hak-hak individual atas tanah". UUPA mengakui hak individual atas tanah, tetapi mempunyai fungsi sosial, UUPA lebih berpihak kepada rakyat dari golongan ekonomi lemah terutama petani karena hak menguasai negara atas agraria untuk sebesar-besarnya kemakmuran rakyat. ${ }^{14}$

Salah satu kegiatan penting untuk mewujudkan tujuan negara dan arah politik hukum pertanahan nasional adalah pendaftaran tanah di seluruh Wilayah Republik Indonesia sebagaimana yang diamanatkan Pasal 19 ayat (1) UUPA. Pendaftaran tanah bertujuan untuk memberikan kepastian hukum dan perlindungan hukum kepada pemegang hak atas suatu bidang tanah. Pendaftaran tanah juga bertujuan untuk mewujudkan tertib administrasi, mencegah terjadinya konflik dan sengketa pertanahan, dan meningkatkan taraf hidup masyarakat. Dengan terselenggaranya pendaftaran tanah, maka pemegang hak atas tanah memiliki kepastian dan dilindungi secara hukum karena sertipikat hak atas tanah memiliki kekuatan pembuktian yang sempurna, selama belum dibuktikan sebaliknya, data fisik dan data yuridis yang dicantumkan dalam sertipikat harus diterima sebagai data yang benar.

Politik hukum pertanahan nasional dalam kegiatan pendaftaran tanah di Indonesia dapat dibagi menjadi tiga periodisasi masa/waktu, yaitu :

1. Masa Orde Lama

Pada masa orde lama, politik hukum sudah mengarah pada upaya mewujudkan pemerataan kemakmuran bagi seluruh rakyat. Melalui program land reform yang sudah diatur dalam Undang-Undang Nomor 56 Tahun 1960 Tentang Penetapan Luas Tanah Pertanian beserta peraturan pelaksanaannya, perombakan struktur penguasaan tanah yang timpang sudah dimulai dengan mengambil alih tanah-tanah kelebihan dari batas maksimum dan tanah-tanah absentee, yang kemudian direncanakan untuk didistribusikan kepada kelompok masyarakat yang

13 Notonagoro, Op Cit. Hlm. 77.

${ }^{14}$ Sri Hajati, dkk. Op Cit. Hlm. 47. 
tidak mempunyai tanah. ${ }^{15}$

Pendistribusian tanah secara merata dinilai sebagai strategi yang langsung dapat memenuhi kebutuhan pokok masyarakat. Perombakan struktur penguasaan dan pemilikan tanah dalam rangka menciptakan pemerataan lebih banyak diprioritaskan pada bidang land reform. Hal tersebut menunjukkan bahwa penguasaan dan pemilikan tanah selama ini tidak merata, hanya dikuasai oleh kelompok tertentu. Selain prioritas pada bidang land reform, bidang-bidang lain yang diatur dalam kebijakan pertanahan pada masa orde lama yaitu pendaftaran tanah.

Pasal 19 ayat (1) UUPA mengamanatkan adanya pendaftaran tanah di seluruh Wilayah Republik Indonesia untuk menjamin kepastian hukum yang diatur dengan peraturan pemerintah. Sebagai tindak lanjut dari Pasal 19 ayat (1) UUPA tersebut, maka Pemerintah membuat Peraturan Pemerintah Nomor 10 Tahun 1961 tentang Pendaftaran Tanah. Pendaftaran hak-hak atas tanah dalam daftar-daftar umum harus dilakukan setelah bidang-bidang tanah yang menjadi obyek hak-hak diukur dan dipetakan. Selama bidang tanah belum diukur dan dipetakan, maka hak-hak yang bersangkutan belum dapat didaftarkan dalam daftar-daftar umum. ${ }^{16}$

Pemerintah Indonesia pada masa orde lama telah merumuskan Peraturan Pemerintah Nomor 10 Tahun 1961 tentang Pendaftaran Tanah sebagai landasan bagi pemerintah dalam melaksanakan pendaftaran tanah di Indonesia. Walaupun Peraturan Pemerintah Nomor 10 Tahun 1961 tentang Pendaftaran Tanah tidak secara eksplisit menegaskan manfaat dan pentingnya dari pendaftaran tanah, namun dengan politik hukum yang dibentuk pada peraturan pemerintah tersebut telah membuktikan bahwa Pemerintah Indonesia pada masa orde lama telah memahami manfaat dan pentingnya pendaftaran tanah.

Pada masa ini, Menteri Agraria menetapkan saat mulai diselenggarakannya pendaftaran tanah secara lengkap disesuatu daerah yang diselenggarakan desa demi desa atau daerah-daerah yang setingkat dengan itu, dalam daerah-daerah yang ditunjuk oleh menteri tersebut diukur semua bidang tanah desa demi desa. Peraturan Pemerintah Nomor 10 Tahun 1961 tentang Pendaftaran Tanah lebih memprioritaskan pada pengaturan pendaftaran tanah secara lengkap, yaitu dengan mengukur dan mendaftarkan bidang tanah desa demi desa yang telah ditetapkan oleh Menteri Agraria. Namun, pendaftaran tanah atas permohonan sendiri atau pendaftaran tanah secara tidak lengkap juga diatur secara implisit dalam Peraturan Pemerintah Nomor 10 Tahun 1961 tentang Pendaftaran Tanah.

Pada masa orde ini sudah dikenal dengan Proyek Operasi Nasional Agraria (PRONA). Pada prinsipnya pendaftaran tanah dilakukan secara lengkap pada desa atau daerah yang telah ditetapkan oleh Menteri Agraria. Hal tersebut sebagai bentuk kepastian hukum yang diberikan oleh pemerintah terhadap subjek dan objek pendaftaran tanah. Pada peraturan pemerintah tersebut sudah mengatur mengenai pengumuman terhadap peta dan daftar isian yang bersangkutan dengan ditempatkan di Kantor Kepala Desa selama 3 bulan, untuk memberikan

${ }^{15}$ Notonagoro, Op Cit. Hlm. 6.

${ }^{16}$ Anonim. Kilas Perkembangan Pendaftaran Tanah. Universitas Sumatera Utara. http://ocw.usu.ac.id/course/download/10500000019-pendaftaran-tanahakta-ppat/kn_603_slide_2. kilas_perkembangan_pendaftaran_tanah.pdf. Diakses pada tanggal 22 Juli 2019. 
kesempatan kepada yang berkepentingan mengajukan keberatan-keberatan mengenai penetapan batas-batas tanah dan isi daftar-daftar isian.

Desa atau daerah yang belum diselenggarakan pendaftaran tanah secara lengkap, dapat mendaftarkan bidang tanahnya atas permohonan yang berhak untuk dibukukan dalam daftar buku tanah. Untuk membukukan hak tersebut, kepada Kepala Kantor Pendaftaran Tanah harus disampaikan surat atau surat-surat bukti hak dan keterangan Kepala Desa yang dikuatkan oleh Asisten Wedana, yang membenarkan surat atau surat-surat bukti hak itu. Selanjutnya Kepala Kantor Pendaftaran Tanah mengumumkan permohonan pembukuan hak itu di Kantor Kepala Desa dan Kantor Asisten Wedana selama 2 bulan berturut-turut. Kalau dianggapnya perlu maka selain pengumuman di Kantor Kepala Desa dan Kantor Asisten Wedana itu, Kepala Kantor Pendaftaran Tanah dapat juga mengumumkan dengan cara lain.

Jika dalam waktu 2 bulan tidak ada yang mengajukan keberatan, maka hak atas tanah itu dibukukan oleh Kepala Kantor Pendaftaran Tanah dalam daftar bukutanah yang bersangkutan. Jika ada yang mengajukan keberatan, Kepala Kantor Pendaftaran Tanah menunda pembukuannya sampai ada keputusan hakim yang membenarkan hak pemohon atas tanah itu. Setelah pembukuan dilaksanakan maka oleh Kepala Kantor Pendaftaran Tanah diberikan kepada pemohon sertifikatsementara yaitu sertifikat tanpa surat-ukur, mempunyai fungsi sebagai sertifikat. Walaupun sertifikat sementara ini dinyatakan memiliki fungsi sebagai sertifikat, namun mengakibatkan ketidakpastian hukum itu sendiri karena sertifikat sementara hanya memberikan kepastian hukum pada subyek, tidak pada obyek pendaftaran tanah sehingga kemungkinan tumpang tindih sertifikat pada bidang tanah yang sama dapat terjadi.

\section{Masa Orde Baru}

Pada masa Orde Baru, terjadi perubahan ideologi pembangunan dari sosialisme ala Indonesia yang dikembangkan oleh Soekarno ke arah kapitalisme beserta anak kandungnya berupa liberalisasi dan swastanisasi penguasaan dan pemanfaatan tanah. Pada awalnya, pemerintah Orde Baru masih mempertahankan peranan Badan Usaha Milik Negara (BUMN) dalam penguasaan dan pemanfaatan/penguasaan tanah bagi kegiatan usaha perkebunan dan industri. Namun dalam perkembangannya, pelan tapi pasti terutama sejak pertengahan dekade 1980-an dan semakin intensif pada awal 1990-an, swastanisasi dan liberalisasi semakin menjadi mainstream dalam kebijakan pertanahan, bahkan semakin mengarah pada komodifikasi tanah yang berdampak negatif bagi perlindungan kepemilikan tanah masyarakat. ${ }^{17}$

Pada masa ini, terjadi pergeseran dari politik pertanahan yang mendorong pemerataan pemilikan tanah sebagai cara mewujudkan kemakmuran rakyat ke arah politik pertanahan yang mendorong ke arah konsentrasi penguasaan dan pemanfaatan tanah pada sekelompok kecil subjek terutama perusahaan besar. Pergeseran ini sejalan dengan logika kapitalisme, yaitu sumber daya tertentu termasuk tanah tidak perlu didistribusikan kepada sebanyak mungkin orang, namun

${ }^{17}$ Notonagoro, Op Cit. Hlm. 7. 
cukup dikuasai dan dimanfaatkan oleh subjek tertentu yang mempunyai kemampuan mengusahakan baik secara permodalan maupun manajemen dan penguasaan teknologi. Melalui konsentrasi penguasaan dan pemanfaatan tanah oleh perusahaan berskala besar diharapkan terjadi pemerataan kemakmuran melalui ketersediaan lapangan kerja dan upah kerja. ${ }^{18}$

Selain terjadi pergeseran politik pertanahan menjadi ke arah konsentrasi penguasan dan pemanfaatan tanah pada sekelompok kecil subjek terutama perusahaan besar, pada tahun 1997 Pemerintah Orde Baru merevisi Peraturan Pemerintah Nomor 10 Tahun 1961 tentang Pendaftaran Tanah menjadi Peraturan Pemerintah Nomor 24 Tahun 1997 tentang Pendaftaran Tanah. Peraturan Pemerintah Nomor 10 Tahun 1961 tersebut selama lebih dari 35 tahun belum cukup memberikan hasil yang memuaskan. Dari sekitar 55 juta bidang tanah hak yang memenuhi syarat untuk didaftar, baru lebih kurang 16,3 juta bidang yang sudah didaftar.

Hal-hal yang merupakan kendala dalam pelaksanaan pendaftaran tanah, disamping kekurangan anggaran, alat dan tenaga, adalah keadaan obyektif tanahtanahnya sendiri yang selain jumlahnya besar dan tersebar di wilayah yang luas, sebagian besar penguasaannya tidak didukung oleh alat-alat pembuktian yang mudah diperoleh dan dapat dipercaya kebenarannya. Selain itu ketentuan hukum untuk dasar pelaksanaannya dirasakan belum cukup memberikan kemungkinan untuk terlaksananya pendaftaran dalam waktu yang singkat dengan hasil yang lebih memuaskan.

Dalam Peraturan Pemerintah Nomor 24 Tahun 1997 tentang Pendaftaran Tanah yang menyempurnakan Peraturan Pemerintah Nomor 10 Tahun 1961 ini, tetap dipertahankan tujuan dan sistem yang digunakan, yang pada hakikatnya sudah ditetapkan dalam Undang-undang Pokok Agraria (UUPA), yaitu bahwa pendaftaran tanah diselenggarakan dalam rangka memberikan jaminan kepastian hukum di bidang pertanahan dan bahwa sistem publikasinya adalah sistem negatif, tetapi yang mengandung unsur positif, karena akan menghasilkan surat-surat tanda bukti hak yang berlaku sebagai alat pembuktian yang kuat, seperti yang dinyatakan dalam Pasal 19 ayat (2) huruf c, Pasal 23 ayat (2), Pasal 32 ayat (2) dan Pasal 38 ayat (2) UUPA. ${ }^{19}$ Peraturan Pemerintah Nomor 24 Tahun 1997 tentang Pendaftaran Tanah merupakan penyempurnaan dari Peraturan Pemerintah Nomor 10 Tahun 1961 tentang Pendaftaran Tanah. Ketentuan yang belum diatur dalam Peraturan Pemerintah Nomor 10 Tahun 1961 tentang Pendaftaran Tanah ditegaskan dalam Peraturan Pemerintah Nomor 24 Tahun 1997 tentang Pendaftaran Tanah. Seperti definisi pendaftaran tanah itu sendiri tidak diatur dalam Peraturan Pemerintah Nomor 10 Tahun 1961 tentang Pendaftaran Tanah, kemudian dijelaskan dalam Peraturan Pemerintah Nomor 24 Tahun 1997 tentang Pendaftaran Tanah. Objek dan tahapan pendaftaran tanah juga tidak dijelaskan secara rinci dalam Peraturan Pemerintah Nomor 10 Tahun 1961 tentang Pendaftaran Tanah, namun oleh Peraturan Pemerintah Nomor 24 Tahun 1997 tentang Pendaftaran Tanah

\footnotetext{
18 Ibid. Hlm. 10.

19 Penjelasan Atas Peraturan Pemerintah Nomor 24 Tahun 1997 tentang Pendaftaran Tanah
} 
disempurnakan dan dijelaskan secara rinci.

Dalam Peraturan Pemerintah Nomor 10 Tahun 1961 tentang Pendaftaran Tanah belum mengatur mengenai tujuan pendaftaran tanah. Namun, dalam Peraturan Pemerintah Nomor 24 Tahun 1997 tentang Pendaftaran Tanah diatur mengenai tujuan pendaftaran tanah sebagaimana disebutkan dalam Pasal 3, yaitu :

a. untuk memberikan kepastian hukum dan perlindungan hukum kepada pemegang hak atas suatu bidang tanah, satuan rumah susun dan hak-hak lain yang terdaftar agar dengan mudah dapat membuktikan dirinya sebagai pemegang hak yang bersangkutan,

b. untuk menyediakan informasi kepada pihak-pihak yang berkepentingan termasuk Pemerintah agar dengan mudah dapat memperoleh data yang diperlukan dalam mengada-kan perbuatan hukum mengenai bidang-bidang tanah dan satuan-satuan rumah susun yang sudah terdaftar;

c. untuk terselenggaranya tertib administrasi pertanahan.

Perubahan mendasar yang terdapat pada Peraturan Pemerintah Nomor 24 Tahun 1997 tentang Pendaftaran Tanah adalah mengenai sertipikat sementara. Pendaftaran tanah yang belum dilakukan secara lengkap dalam Peraturan Pemerintah Nomor 10 Tahun 1961 tentang Pendaftaran Tanah diberikan sertipikat sementara, yaitu sertipikat tanpa surat ukur. Hal tersebut dapat mengakibatkan ketidakpastian hukum karena sertifikat sementara hanya memberikan kepastian hukum pada subyek, tidak pada obyek pendaftaran tanah sehingga kemungkinan tumpang tindih sertifikat pada bidang tanah yang sama dapat terjadi. Kemudian dalam Peraturan Pemerintah Nomor 24 Tahun 1997 tentang Pendaftaran Tanah sertipikat sementara dihapus, artinya sertipikat sudah menjamin kepastian hukum terhadap pemilik tanah karena subjek dan objek pendaftaran tanahnya jelas.

Perubahan mendasar lainnya yang terdapat pada Peraturan Pemerintah Nomor24 Tahun 1997 tentang Pendaftaran Tanah adalah mengenai jangka waktu pengumuman data fisik dan data yuridis, baik terhadap pendaftaran tanah secara sistematis (lengkap) maupun pendaftaran tanah secara sporadik (tidak lengkap). Jangka waktu pengumuman pendaftaran tanah secara lengkap dalam Peraturan Pemerintah Nomor 10 Tahun 1961 tentang Pendaftaran Tanah dilakukan selama 3 bulan dan pendaftaran tanah secara tidak lengkap dilakukan selama 2 bulan berturutturut. Sedangkan jangka waktu pengumuman dalam Peraturan Pemerintah Nomor 24 Tahun 1997 tentang Pendaftaran Tanah yaitu 30 (tiga puluh) hari untuk pendaftaran tanah secara sistematis dan 60 (enam puluh) hari untuk pendaftaran tanah secara sporadik.

Jangka waktu pengumuman dalam Peraturan Pemerintah Nomor 10 Tahun 1961 tentang Pendaftaran Tanah dirasakan sangat lama sehingga menghambat semangat pendaftaran tanah di seluruh Wilayah Republik Indonesia. Hal tersebut dapat terbukti bahwa selama lebih dari 35 tahun belum cukup memberikan hasil pendaftaran tanah yang memuaskan. Dari sekitar 55 juta bidang tanah hak yang memenuhi syarat untuk didaftar, baru lebih kurang 16,3 juta bidang yang sudah didaftar. Oleh karena itu, untuk mempercepat pendaftaran tanah di Indonesia, maka 
Pemerintah Indonesia Orde Baru meringkaskan jangka waktu pengumuman menjadi lebih cepat dalam Peraturan Pemerintah Nomor 24 Tahun 1997 tentang Pendaftaran Tanah.

\section{Masa Reformasi}

Pada masa Orde Reformasi, semangat kebijakan kapitalistik, liberal dan persaingan tidak mengalami perubahan. Artinya, kebijakan pertanahan masih melanjutkan yang sudah dipraktikkan pada masa Orde Baru, bahkan instansi sektoralisme kebijakan yang kapitalistik dan liberal semakin meningkat. ${ }^{20}$ Politik hukum pertanahan dalam kegiatan pendaftaran tanah pun tidak mengalami perubahan karena sampai saat ini peraturan pemerintah yang mengatur mengenai pendaftaran tanah masih diatur dalam Peraturan Pemerintah Nomor 24 Tahun 1997 tentang Pendaftaran Tanah.

Pendaftaran tanah di Indonesia selama ini belum maksimal, jumlah bidang tanah yang sudah terdaftar baru sekitar \pm 58 juta dari total \pm 126 juta bidang tanah Indonesia, artinya terdapat \pm 68 juta bidang tanah yang belum terdaftar. Dengan masih rendahnya pendaftaran tanah tersebut, sudah tentu akan menimbulkan berbagai permasalahan pertanahan. Permasalahan pertanahan yang seringkali terjadi di masyarakat antara lain, yaitu tidak adanya pemerataan dalam pemilikan dan atau penguasaan tanah; adanya penguasaan tanah tanpa izin yang berhak atau kuasanya; dan banyaknya sengketa batas. ${ }^{21}$

Pendaftaran tanah bertujuan untuk memberikan kepastian hukum dan perlindungan hukum kepada pemegang hak atas suatu bidang tanah. Pendaftaran tanah juga bertujuan untuk mewujudkan tertib administrasi, mencegah terjadinya konflik dan sengketa pertanahan, dan meningkatkan taraf hidup masyarakat. Dengan terselenggaranya pendaftaran tanah, maka pemegang hak atas tanah memiliki kepastian dan dilindungi secara hukum karena sertipikat hak atas tanah memiliki kekuatan pembuktian yang sempurna, selama belum dibuktikan sebaliknya, data fisik dan data yuridis yang dicantumkan dalam sertipikat harus diterima sebagai data yang benar.

Pendaftaran tanah di Indonesia yang masih rendah selama ini membuat Pemerintah Indonesia melalui Kementerian Agraria dan Tata Ruang/Badan Pertanahan Nasional membentuk regulasi percepatan pendaftaran tanah, yaitu melalui kebijakan Pendaftaran Tanah Sistematis Lengkap (PTSL). Dalam rangka percepatan pendaftaran tanah telah diterbitkan Peraturan Menteri Agraria dan Tata Ruang/Kepala BPN No. 35 Tahun 2016 tentang Percepatan Pelaksanaan Pendaftaran Tanah Sistematis Lengkap sebagaimana telah diubah dengan Peraturan Menteri Agraria dan Tata Ruang/ Kepala BPN No. 01 Tahun 2017 tentang Perubahan Atas Peraturan Menteri Agraria dan Tata Ruang/Kepala BPN No. 35 Tahun 2016 tentang Percepatan Pelaksanaan Pendaftaran Tanah Sistematis Lengkap, selanjutnya diamandemen kembali menjadi Peraturan Menteri Agraria dan Tata Ruang/Kepala BPN No. 12 Tahun 2017 tentang Percepatan Pendaftaran Tanah Sistematis Lengkap dan

${ }^{20}$ Notonagoro, Op. Cit., Hlm. 11. 
terakhir diubah kembali menjadi Peraturan Menteri Agraria dan Tata Ruang/Kepala BPN No. 6 Tahun 2018 tentang Pendaftaran Tanah Sistematis Lengkap.

Kebijakan PTSL memiliki perbedaan yang mendasar dibandingkan dengan PRONA, karena jumlah bidang tanah dalam pendaftaran tanah pertama kali melalui PRONA bersifat terbatas, sedangkan pada pendaftaran tanah melalui PTSL tidak dibatasi jumlahnya. Hal tersebut sebagaimana yang diatur dalam Pasal 1 Angka 2 Peraturan Menteri Agraria dan Tata Ruang/Kepala BPN No. 6 Tahun 2018 tentang Pendaftaran Tanah Sistematis Lengkap bahwa "PTSL merupakan kegiatan pendaftaran tanah untuk pertama kali yang dilakukan secara serentak bagi semua objek pendaftaran tanah di seluruh wilayah Republik Indonesia dalam satu wilayah desa/kelurahan atau nama lainnya yang setingkat dengan itu, yang meliputi pengumpulan data fisik dan data yuridis mengenai satu atau beberapa objek pendaftaran tanah untuk keperluan pendaftarannya".

Menurut Lawrence M Friedman bahwa berhasil atau tidaknya penegakan hukum bergantung pada tiga unsur, yaitu substansi hukum, struktur hukum dan budaya hukum. Salah satu unsur yang penting dalam berhasil atau tidaknya penegakan hukum yaitu substansi hukum. Substansi hukum yaitu norma dan aturan yang terdapat pada suatu negara. Dalam kegiatan pendaftaran tanah sudah terdapat aturan yang mengatur, yaitu Undang-Undang Nomor 5 Tahun 1960 tentang Peraturan Dasar Pokok-Pokok Agraria (UUPA), Peraturan Pemerintah Nomor 24 Tahun 1997 tentang Pendaftaran Tanah, dan Peraturan Menteri Agraria dan Tata Ruang/Kepala BPN No. 6 Tahun 2018 tentang Pendaftaran Tanah Sistematis Lengkap. Memang substansi hukum terpenuhi karena sudah terdapat peraturan yang mengatur mengenai pendaftaran tanah. Namun, terdapat pertentangan antara peraturan yang lebih rendah dengan peraturan yang lebih tinggi (Lex Superior Derogat Legi Inferior).

Menurut Hans Kelsen, sumber pedoman adalah dari grandnurm (norma dasar). Dengan menggunakan konsep Stufenbau (lapisan-lapisan aturan menurut eselon), Hans Kelsen mengkonstruksi pemikiran tentang tertib yuridis. Dalam konstruksi ini, ditentukan jenjang-jenjang perundang-undangan. Seluruh sistem perundangundangan mempunyai suatu struktur piramidal, mulai dari yang abstrak yakni grandnurm sampai yang konkret seperti undang-undang, peraturan pemerintah, dan lain sebagainya. ${ }^{21}$ Norma dasar pertanahan di Indonesia adalah Pasal 33 ayat (3) Undang-Undang Dasar RI 1945 agar mengatur penggunaan sumber daya alam termasuk tanah untuk meningkatkan kemakmuran seluruh rakyat Indonesia. Amanah tersebut selanjutnya dikonkretkan dalam Undang-Undang Nomor 5 tahun 1960 tentang Peraturan Dasar Pokok-Pokok Agraria (UUPA), yang selanjutnya dikonkretkan lebih rinci dengan peraturan pemerintah.

Hierarki tata urutan peraturan perundang-undangan di Indonesia diatur dalam Undang-Undang Nomor 12 Tahun 2011 tentang Pembentukan Peraturan Perundangundangan. Pasal 7 ayat (1) Undang-Undang Nomor 12 Tahun 2011 tentang Pembentukan Peraturan Perundang-undangan menyatakan bahwa "Jenis dan hierarki Peraturan Perundang-undangan terdiri atas:

${ }^{21}$ Bernard L. Tanya dkk, Teori Hukum Strategi Tertib Manusia Lintas Ruang dan Generasi, Yogyakarta, Genta Publishing, 2013, Hlm. 115. 
a. Undang-Undang Dasar Negara Republik Indonesia Tahun 1945;

b. Ketetapan Majelis Permusyawaratan Rakyat;

c. Undang-Undang/Peraturan Pemerintah Pengganti Undang-Undang;

d. Peraturan Pemerintah;

e. Peraturan Presiden;

f. Peraturan Daerah Provinsi; dan

g. Peraturan Daerah Kabupaten/Kota.

Peraturan Menteri tidak masuk dalam hierarki sebagaimana yang disebutkan dalam Pasal 7 ayat (1) Undang-Undang Nomor 12 Tahun 2011 tentang Pembentukan Peraturan Perundang-undangan. Namun, Peraturan Menteri diatur dalam Pasal 8 ayat (1) dan ayat (2) Undang-Undang Nomor 12 Tahun 2011 tentang Pembentukan Peraturan Perundang-undangan. Pasal tersebut menyatakan pada pokoknya bahwa peraturan menteri diakui keberadaannya dan mempunyai kekuatan hukum mengikat sepanjang diperintahkan oleh Peraturan Perundang-undangan yang lebih tinggi atau dibentuk berdasarkan kewenangan.

Peraturan yang bertentangan satu dengan lainnya yaitu Peraturan Pemerintah Nomor 24 Tahun 1997 tentang Pendaftaran Tanah dengan Peraturan Menteri Agraria dan Tata Ruang/Kepala BPN No. 6 Tahun 2018 tentang Pendaftaran Tanah SistematisLengkap, yaitu yang berkaitan dengan jangka waktu pengumuman data fisik dan data yuridis. Jangka waktu pengumuman sebagaimana diatur Pasal 24 Peraturan Menteri Agraria dan Tata Ruang/Kepala BPN No. 6 Tahun 2018 tentang Pendaftaran Tanah Sistematis Lengkap yaitu 14 hari kalender di Kantor Panitia Ajudikasi PTSL dan Kantor Kepala Desa/Kelurahan. Sedangkan dalam Pasal 26 Peraturan Pemerintah Nomor 24 Tahun 1997 tentang Pendaftaran Tanah diumumkan selama 30 (tiga puluh) hari.

Peraturan Menteri Agraria dan Tata Ruang/Kepala BPN No. 6 Tahun 2018 tentang Pendaftaran Tanah Sistematis Lengkap khususnya mengenai pengumuman data fisik dan data yuridis merupakan perintah dari Peraturan Pemerintah Nomor 24 Tahun 1997 tentang Pendaftaran Tanah. Namun, ketentuan lebih lanjut mengenai pelaksanaan ketentuan pengumuman yang dimaksud dalam Pasal 26 ayat (4) Peraturan Pemerintah Nomor 24 Tahun 1997 tentang Pendaftaran Tanah yang ditetapkan oleh Menteri sebenarnya hanya untuk pelaksanaan teknis pengumuman, bukan untuk merubah jangka waktu pengumuman data fisik dan data yuridis. Oleh karena itu, Peraturan Menteri Agraria dan Tata Ruang/Kepala BPN No. 6 Tahun 2018 tentang Pendaftaran Tanah Sistematis Lengkap harus disesuaikan dengan Peraturan Pemerintah Nomor 24 Tahun 1997 tentang Pendaftaran Tanah khususnya mengenai jangka waktu pengumuman data fisik dan data yuridis.

Kebijakan dari Presiden bersama dengan Kementerian Agraria dan Tata Ruang/Badan Pertanahan Nasional untuk melakukan percepatan pendaftaran tanah di Indonesia melalui penerbitan Peraturan Menteri Agraria dan Tata Ruang/Kepala BPN No. 6 Tahun 2018 tentang Pendaftaran Tanah Sistematis Lengkap patut di apresiasi. Kementerian Agraria dan Tata Ruang/Badan Pertanahan Nasional dari yang sebelumnya hanya berhasil melakukan pendaftaran tanah setiap tahunnya sekitar 1 juta bidang tanah, tahun 2017 sudah berhasil melakukan pendaftaran tanah sebanyak 5 juta bidang tanah, dan pada tahun 2018 sebanyak 7 juta bidang tanah, serta pada 
tahun 2019 ditargetkan 9 juta bidang tanah. Namun, regulasi yang mengatur juga harus diperhatikan secara bersama agar peraturan yang satu dengan peraturan yang lainnya tidak saling bertentangan. Oleh karena peraturan yang bertentangan adalah peraturan pelaksana dari UUPA, artinya peraturan yang bertentangan tersebut merupakan produk dari pemerintah, maka pemerintah perlu mengkaji kembali dan melakukan sinkronisasi peraturan mengenai pendaftaran tanah.

\section{Kesimpulan}

Politik hukum pertanahan nasional dalam kegiatan pendaftaran tanah di Indonesia dapat dibagi menjadi tiga periodisasi masa/waktu, yaitu masa Orde Lama, Orde Baru dan Orde Reformasi. Pada masa Orde Lama, sebagai amanat dari Pasal 19 ayat (1) UUPA, maka pemerintah merumuskan Peraturan Pemerintah Nomor 10 Tahun 1961 tentang Pendaftaran Tanah sebagai landasan bagi pemerintah dalam melaksanakan pendaftaran tanah di Indonesia. Kegiatan pendaftaran tanah dalam Peraturan Pemerintah Nomor 10 Tahun 1961 tentang Pendaftaran Tanah dilakukan dengan dua cara yaitu secara lengkap dan tidak lengkap. Jangka waktu pengumuman data fisik dan yuridis pada pendaftaran tanah secara lengkap yaitu 3 bulan dan apabila tidak ada keberatan diberikan sertipikat hak atas tanah, sedangkan pada pendaftaran tanah secara tidak lengkap diumumkan selama 2 bulan dan apabila tidak terdapat keberatan diberikan sertipikat sementara, yaitu sertipikat tanpa surat ukur.

Pada masa Orde Baru, Pemerintah Orde Baru merevisi Peraturan Pemerintah Nomor 10 Tahun 1961 tentang Pendaftaran Tanah menjadi Peraturan Pemerintah Nomor 24 Tahun 1997 tentang Pendaftaran Tanah karena Peraturan Pemerintah Nomor 10 Tahun 1961 tersebut selama lebih dari 35 tahun belum cukup memberikan hasil yang memuaskan. Oleh karena itu, jangka waktu pengumuman yang diatur dalam Peraturan Pemerintah Nomor 24 Tahun 1997 tentang Pendaftaran Tanah di ubah menjadi 30 hari untuk pendaftaran tanah secara sistematis dan 60 hari untuk pendaftaran tanah secara sporadik, dan apabila tidak terdapat keberatan diberikan sertipikat hak atas tanah.

Pada masa Orde Reformasi, Politik hukum pertanahan dalam kegiatan pendaftaran tanah tidak mengalami perubahan karena sampai saat ini peraturan pemerintah yang mengatur mengenai pendaftaran tanah masih diatur dalam Peraturan Pemerintah Nomor 24 Tahun 1997 tentang Pendaftaran Tanah. Pendaftaran tanah di Indonesia yang masih rendah selama ini membuat Pemerintah Indonesia melalui Kementerian Agraria dan Tata Ruang/Badan Pertanahan Nasional membentuk regulasi percepatan pendaftaran tanah, yaitu melalui kebijakan Pendaftaran Tanah Sistematis Lengkap (PTSL) yang terakhir diatur dengan Peraturan Menteri Agraria dan Tata Ruang/Kepala BPN No. 6 Tahun 2018 tentang Pendaftaran Tanah Sistematis Lengkap. Salah satu hal yang di ubah dalam peraturan menteri tersebut yaitu mengenai jangka waktu pengumuman menjadi 14 hari, lebih cepat dari yang diatur dalam peraturan pemerintah.

Kementerian Agraria dan Tata Ruang/Badan Pertanahan Nasional dari yang sebelumnya hanya berhasil melakukan pendaftaran tanah setiap tahunnya sekitar 1 juta bidang tanah, tahun 2017 sudah berhasil melakukan pendaftaran tanah sebanyak 5 juta bidang tanah, dan pada tahun 2018 sebanyak 7 juta bidang tanah, serta pada 
tahun 2019 ditargetkan 9 juta bidang tanah. Namun, regulasi yang diterbitkan pemerintah harus diperhatikan karena Peraturan Menteri Agraria dan Tata Ruang/Kepala BPN No. 6 Tahun 2018 tentang Pendaftaran Tanah Sistematis Lengkap bertentangan dengan Peraturan Pemerintah Nomor 24 Tahun 1997 tentang Pendaftaran Tanah khususnya mengenai jangka waktu pengumuman data fisik dan data yuridis.

\section{Saran}

Peraturan yang bertentangan dalam pendaftaran tanah sistematis lengkap adalah peraturan pelaksana dari UUPA, artinya peraturan yang bertentangan tersebut merupakan produk dari pemerintah, maka pemerintah perlu mengkaji kembali dan melakukan sinkronisasi peraturan mengenai pendaftaran tanah.

\section{Daftar Pustaka}

\section{Buku :}

Arba, Hukum Agraria Indonesia. Sinar Grafika. Jakarta.

Hajati, Sri, Sri Winarsi, Agus Sekarmadji, Oemar Moechtar. Buku Ajar Politik Hukum Pertanahan. Airlangga University Press. Surabaya. 2018.

Ismail, Nurhasan. Hukum Agraria Dalam Tantangan Perubahan. Setara Press. Malang. 2018.

Kurniati, Nia. Hukum Agraria Sengketa Pertanahan Penyelesaiannya Melalui Arbitrase Dalam Teori dan Praktik. PT Refika Aditama. Bandung. 2016.

Notonagoro. Politik Hukum dan Pembangunan Agraria Di Indonesia. Bina Aksara. Jakarta. 1984.

Soetiknjo, Iman. Politik Agraria Nasional. Gadjah Mada University Press. Yogyakarta. 1985. Tanya, Bernard L, Yoan N. Simanjuntak, Markus Y. Hage. Teori Hukum Strategi Tertib.

Manusia Lintas Ruang dan Generasi. Genta Publishing. Yogyakarta. 2013.

\section{Internet :}

Anonim. Kilas Perkembangan Pendaftaran Tanah. Universitas SumateraUtara. http:/ /ocw.usu.ac.id/course/download/10500000019-pendaftaran-tanah-aktappat/kn_603_slide_2.kilas_perkembangan_pendaftaran_tanah.pdf. Diakses pada tanggal 22 Juli 2019.

\section{Peraturan Perundang-undangan :}

Undang-Undang Dasar Negara Republik Indonesia Tahun 1945 
Undang-Undang Nomor 5 Tahun 1960 tentang Peraturan Dasar Pokok-Pokok Agraria Peraturan Pemerintah Nomor 10 Tahun 1961 tentang Pendaftaran Tanah

Peraturan Pemerintah Nomor 24 Tahun 1997 tentang Pendaftaran Tanah

Peraturan Menteri Agraria dan Tata Ruang/Kepala BPN No. 6 Tahun 2018 tentang Pendaftaran Tanah Sistematis Lengkap 